\title{
ANALISIS MAKNA ORNAMEN RUMAH GADANG DALAM PERSPEKTIF FILSAFAT PENDIDIKAN
}

\author{
Nurulfatmi Amzy \\ Program Studi Desain Komunikasi Visual \\ Fakultas Bahasa Dan Seni, Universitas Indraprasta PGRI \\ Jl. Nangka 58, Tanjung Barat (TB Simatupang) Jagakarsa, Jakarta Selatan \\ nurulfatmiamzy@gmail.com
}

\begin{abstract}
Abstrak
Setiap ornamen pada benda pusaka dibuat bukan hanya untuk kepentingan estetis belaka, tapi juga untuk tujuan simbolis. Ada pesan yang ingin disampaikan lewat simbol-simbol yang ada pada ornamen tersebut. Sejumlah pesan juga terdapat pada ornamen Rumah Gadang, rumah tradisional suku Minangkabau. Dalam ornamen tersebut tertuang falsafah hidup adat Minangkabau, yaitu alam takambang jadi guru. Falsafah tersebut mendidik orang Minang untuk memperhatikan alam dengan baik karena alam menyimpan pelajaran hidup yang tiada batasnya. Dengan menggunakan metode hermeneutika, sebuah ornamen coba ditafsirkan maknanya. Kemudian, makna tersebut dianalisis dengan menggunakan teori Filsafat Pendidikan Progresivisme yang diusung oleh John Dewey. Tujuan dari penulisan ini adalah untuk menginformasikan bahwa ada kesamaan dari cara adat Minangkabau mendidik manusianya dengan tujuan Pendidikan Filsafat Progresivisme. Keduanya menitikberatkan pada pengalaman langsung sebagai sumber dari pengetahuan itu sendiri.
\end{abstract}

Kata kunci : Ornamen, Minangkabau, Filsafat Pendidikan, Progresivisme, Pengalaman.

\begin{abstract}
Ornaments in any cultural heritage was made not just for aestethic purpose, but also for a symbolic order. There was a message that want to be delivered through the symbolization in it. A number of messages were concluded in Rumah Gadang's ornaments, the traditional house of Minangkabau ethnic group. The ornaments tell us about the Minangkabau philosophy of life, alam takambang jadi guru. That philosophy have taught the Minangnese to put their attention into nature for it spreads unlimited knowledge. Through hermeneutics, the paper spots an ornament to investigate its meanings. Then, those meanings would be analysed with the perspective of Progressivism of the Philosophy of Education by John Dewey. The purpose of this paper is to inform that there is a similarity between the way Minangkabau Tradition teach the people and the aim of Progressivism of the Philosophy of Education. Both of them put the direct personal experience in the basis of education.
\end{abstract}

Keywords : Ornament, Minangkabau, Philosophical Education, Progressivism, Experience. 


\section{PENDAHULUAN}

Kebudayaan itu seperti jati diri yang harus terus dijaga. Membiarkannya luput dimakan waktu sama saja membiarkan jiwa lepas dari tubuhnya tanpa ada usaha berarti. Agar nilai-nilai dalam kebudayaan tetap mengakar kuat, salah satu usaha yang bisa dilakukan adalah meninggalkan benda pusaka atau yang biasa disebut dengan warisan budaya. Benda pusaka merupakan artefak atau kebudayaan fisik yang di dalamnya terdapat manifestasi pemikiran dan nilainilai sebuah kebudayaan. Pusaka tersebut tidak hanya menjadi pengingat suatu kebudayaan itu pernah ada, namun juga sebagai bentuk komunikasi visual antara generasi terdahulu dengan generasi setelahnya. Sebuah penyampai pesan dengan tujuan untuk menjadi pedoman bagi penerus kebudayaan. Penunjuk cara bagaimana bersikap yang baik terhadap diri sendiri dan lingkungan.

Salah satu warisan budaya sarat makna itu adalah Rumah Gadang, rumah bagonjong milik urang ranah minang dari Sumatera Barat. Orang bilang, membangun rumah sama saja artinya dengan membangun peradaban. Sukses tidaknya seseorang dilihat dari keadaan dalam rumahnya dulu. Sehingga, banyak orang yang tidak mau sembarangan dalam membangun rumahnya. Pembangunan rumah tidak bisa disebut pekerjaan sambil lalu. Perlu pemikiran yang matang agar rumah dapat terasa damai untuk ditinggali. Rumah adalah implementasi dari cara manusia berpikir. Dengan kata lain, rumah adalah representasi dari diri pribadi yang meninggalinya.

Dengan demikian, kita tahu bahwa perlu perencanaan yang matang untuk membangun sebuah rumah, terlebih rumah pusaka yang akan diturunkan ke sejumlah generasi setelahnya. Dalam pembangunan Rumah
Gadang, setiap detailnya diperhatikan dengan jeli. Pembagian ruang, kualitas bahan material dan tampilannya diperhatikan dengan baik.

Lebih dari sekedar tempat tinggal, Rumah Gadang hadir sebagai alat komunikasi antar masa. Layaknya sebuah komunikasi, harus ada pesan yang tersampaikan lewat bahasa tersebut. Struktur, arsitektur dan ornamen pada Rumah Gadang merupakan salah satu sarana untuk memaksimalkan komunikasi tersebut. Namun sekarang, banyak orang tidak paham dengan makna yang ada di setiap detail rumah pusaka itu.

Dengan alasan itulah penulis mencoba untuk menggali makna dibalik detail Rumah Gadang, agar didapatkan pengetahuan tentang pesan apa yang ingin disampaikan di dalamnya. Namun, kali ini penulis hanya akan memfokuskan pembicaraan kepada ornamennya saja.

Jika dilihat secara kasat mata, maka mata kita akan langsung menangkap sebuah pengetahuan bahwa ornamen Rumah Gadang terisnpirasi dari alam semesta. Terbukti dari motif yang terukir di sana adalah motif berbentuk dedaunan dan bebungaan. Orang Minang memang sangat menghargai alam. Hidup dengan alam artinya belajar dari alam. Dengan kata lain, mereka menjadikan alam sebagai sumber pengetahuan. Dan semua itu tertuang dalam sejumlah ornamen di dalamnya.

Berbicara mengenai sumber pengetahuan artinya kita bicara tentang landasan sebuah ilmu pengetahuan. Dan itu termaktub dalam pandangan Filsafat Pendidikan. Lewat tulisan ini, penulis ingin menggali lebih dalam ornamen yang terukir di dinding Rumah Gadang, untuk kemudian dilihat apakah memang ada kesesuaian antara prinsip hidup orang Minang dalam berpengetahuan dengan ajaran Filsafat Pendidikan. 


\section{Hermeneutika Sebagai Sebuah Metode Pemahaman}

Untuk mendapatkan kesimpulan yang dapat dipertanggungjawabkan, penulis tidak mau sembarangan dalam mengkaji makna yang terdapat dalam ornamen Rumah Gadang. Oleh karena itu, penulis menggunakan metode untuk membahasnya, agar tetap pada jalur yang seharusnya.

Metode yang penulis gunakan adalah metode filsafat, yaitu Hermenuetika. Hermeneutika itu sendiri berasal dari bahasa Yunani, yaitu hermeneuein yang berarti "menafsirkan". Maka kata benda hermeneuia secara harfiah artinya "penafsiran" (Sumaryono, 2016: 23).

Hans-Georg Gadamer mengatakan bahwa hermeneutika bukan persoalan metode, melainkan usaha untuk memahami dan menginterpretasi sebuah teks. Hermeneutika merupakan bagian keseluruhan pengalaman mengenai dunia. Hermenutika berhubungan dengan suatu techne (ilmu tentang seni) tertentu dan berusaha kembali ke susunan tata bahasa, aspek kata-kata retorik dan aspek dialektik sesuatu bahasa. Itulah mengapa hermeneutika juga merupakan ilmu pengetahuan tentang segala yang universal yang mungkin untuk diajarkan (Sumaryono, 2016: 84).

Menginterpretasikan adalah jalan untuk memahami sesuatu. Setelah pemahaman itu ada, akan ada pengetahuan baru yang akan menambah khasanah ilmu pengetahuan. Maka, mungkin sekali untuk diajarkan.

Dengan menggunakan metode tersebut, penulis akan mencoba untuk meninterpretasikan makna-makna dalam ornamen yang terukir di dinding Rumah Gadang. Setelah makna ornamen tersebut didaptkan, akan diketahui sebuah pemahaman baru mengenai hubungan antara pendidikan orang Minang dengan pendidikan dalam kacamata Filsafat.
Kedepannya, diharapkan bahwa apa yang penulis simpulkan nanti dapat menambah kasanah pengetahuan dalam ilmu budaya dan juga ilmu pendidikan di negeri ini.

\section{PEMBAHASAN}

\section{Ornamen pada Rumah Gadang}

Ornamen berasal dari bahasa latin ornare yang artinya menghiasi. Menurut Gustami dalam Sunaryo (2009), ornamen adalah komponen produk seni yang ditambahkan atau sengaja dibuat untuk tujuan sebagai hiasan. Jadi berdasarkan pengertian itu, ornamen merupakan penerapan hiasan pada suatu produk. Fungsi utama dari dari sebuah ornamen adalah untuk memperindah benda produk atau barang yang dihias. Penambahan ornamen pada sebuah produk umumnya untuk membuatnya menjadi lebih menarik, dalam arti estetis, oleh karena itu menjadi lebih bernilai. Yang demikian itu berakibat meningkatnya penghargaan terhadap produk benda bersangkutan, baik secara spiritual maupun material (Sunaryo, 2009: 3).

Tujuan tersebut terlihat jelas implikasinya pada ornamen Rumah Gadang. Adanya ukiran-ukiran bermotif pada dindingnya meningkatkan daya tarik rumah adat Sumatera Barat ini. Namun, disamping tujuan estetisnya, tersingkap pula sebuah tujuan lain yang ingin dihadirkan pada ornamen tersebut. Ada pesan yang tersimpan di setiap ornamen yang terukir di dinding-dinding kayu itu. Pesan yang seharusnya ditangkap oleh generasi sekarang ini untuk dijadikan sebagai bahan perenungan. Ya, di dalamnya ada prinsip-prinsip orang Minangkabau dalam menjalani hidup.

Hal tersebut sejalan dengan fungsi ornamen yang selanjutnya, yaitu fungsi simbolis. Fungsi simbolis ornamen pada umumnya dijumpai pada produk-produk benda upacara atau benda-benda pusaka, 
mengikuti nilai estetisnya (Sunaryo, 2009: 5).

Sebagai warisan budaya atau benda pusaka dari sebuah kebudayaan, maka tidak heran mengapa banyak orang berkata bahwa keelokan Rumah Gadang menyimpan banyak petuah atau pelajaran hidup. Pelajaran tersebut tertuang dalam simbol-simbol yang hadir dalam ornamennya.

Lewat ornamen tersebut, tertuang sebuah falsafah yang mendasari hidup orang Minangkabau, yaitu alam takambang jadi guru. Alam terkembang di depan mata manusia tidak lain adalah untuk mengajarinya banyak hal. Alam dan pengalaman yang hadir bersamanya adalah guru terbaik dari segala macam guru. Maka tidak heran mengapa motif ornamen Rumah Gadang adalah motifmotif flora dan fauna, karena memang terinspirasi dari alam itu sendiri.

Oleh karena itu, penamaan ornamen Rumah Gadang tidak asalasalan. Setiap nama ukirannya melambangkan gejala hidup masyarakat yang menjadi pedoman dalam penyelenggaraan kehidupan masyarakat Minangkabau. Dari segi bentuknya, yang mula-mula timbul adalah bentuk realis, yaitu meniru bentuk alam seperti apa yang dilihatnya. Tetapi kemudian, bentuk-bentuk alam itu mulai ada yang dirubah sesuai dengan pandangan dan selera pembuatnya. Tetapi bukan berarti bentuk realis tersebut ditinggalkan begitu saja. Biasanya, kedua bentuk itu akan dikombinasikan dalam sebuah ukiran. (https://ninkarch.files.wordpress.com/2008/11/ ars-nus-tgs-besar.pdf)

Ukiran adat Minangkabau tidak memiliki pola tertentu, sesuai dengan sifat gejala alam yang sukar dibuat polanya. Pola ukiran Minangkabau terletak pada pikiran dan keahlian masingmasing tukar ukir. Proses pemindahan bentuk alam ke bentuk ukiran hanya terjadi dengan melihat bentuk alam, kemudian melalui proses abstraksi alam pikirannya, lalu dipahatkan ke atas kayu yang hendak diukir. (https://ninkarch.files.wordpress.com/2008/11/ ars-nus-tgs-besar.pdf)

Motif abstrak tersebut terlihat di beberapa ornamen Rumah Gadang seperti berikut;

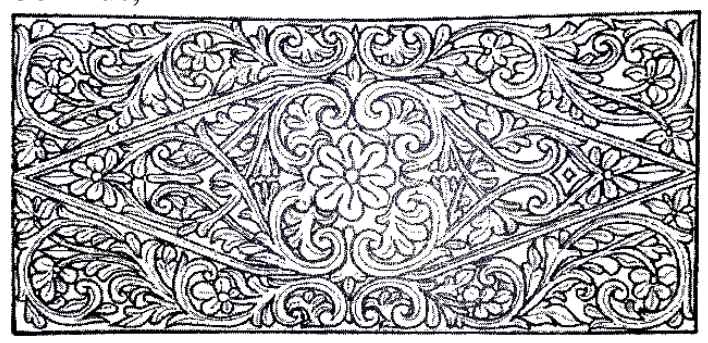

Gambar 1.

Motif Kuciang Lalok Jo Saik Galamai Sumber: Buku Ornamen Nusantara

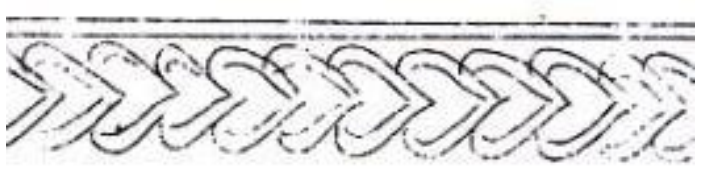

Gambar 2.

Motif Bada Mudiak

Sumber: http://zulfikri.orgfree.com/

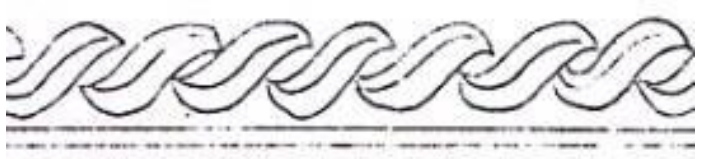

Gambar 3.

Motif Itiak Pulang Patang

Sumber: http://zulfikri.orgfree.com/

Motif ukir Kuciang Lalok (kucing tidur) terlihat tidak ada kucingnya. Dalam ukiran bahkan lebih mencitrakan motif tumbuh-tumbuhan dengan di bagian tengahnya terdapat empat buah lengkungan berikal dalam konfigurasi setangkup. Demikian pula pada motif ukir Bada Mudiak (ikan teri) atau Itiak Pulang Patang (itik pulang petak), orang hanya menemukan motif berbentuk garis tekuk berulang atau lengkung seperti huruf " $\mathrm{S}$ " dan tidak dapat menemukan sosok ikan atau itiknya. (Sunaryo, 2009: 187).

Itulah sebagian motif ornamen berbentuk ukiran yang abstrak pada 
Rumah Gadang. Namun kali ini, penulis akan fokus mengkaji satu motif yang juga memiliki syair sebagai penjelas makna pada motif tersebut. Untuk kemudian, hasil dari pemaknaan tersebut akan dianalisis dengan kaca mata Filsafat Pendidikan setelahnya.

\section{Motif Ornamen Lumuik Hanyuik}

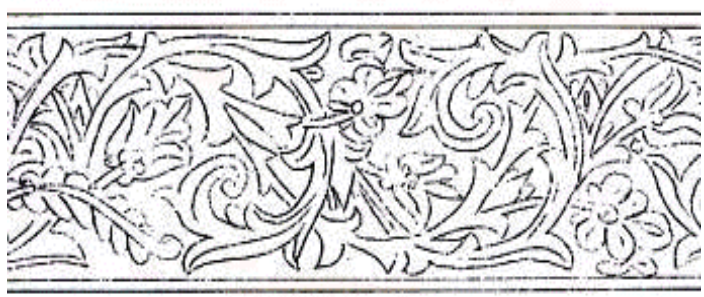

Gambar 4.

Motif Lumuik Hanyuik.

Sumber: http://zulfikri.orgfree.com/

Adapun syair terkait dengan motif Lumuik Hanyuik (Lumut Hanyut) adalah sebagai berikut:

Aka lapuak gagangnyo lapuak.

Hiduik nan indak mamiliah tampek.

Asa lai lambah, inyo lah tumbuah.

Dalam aia bagagang juo.

Aia hilia lumuik pun hilia.

Walau tasalek di ruang batu.

Baguba babondong-bondong.

Aia bapasang lumuik bapiuah.

Namun hiduik bapantang mati.

Baitu untuangnyo lumuik.

Indak mancari tampek diam.

Hanyo manompang jo aia hilia.

Indak mamiliah tampek tumbuah.

Asa kasampai ka muaro.

Usah cameh badan kahanyuik.

Baguru kito kalumuik.

Alam takambang jadi guru.

Lahianyo lumuik nan disabuik.

Bathinnyo Adat Minangkabau.

Dari syair tersebut diketahui bahwa ketika kita berbicara mengenai inti dari adat Minangkabau (bathinnyo adat minangkabau), maka tidak bisa tidak membicarakan tumbuh dan cara hidupnya lumut seperti apa.

Artinya, hidup orang Minangkabau sudah seharusnya mengikuti cara hidup lumut. Hidup yang bagaimana? Yaitu hidup yang berpindah, tidak diam di satu tempat. Seperti lumut yang hanyut dibawa arus, selama ia masih di dalam air, ia masih akan tetap hidup.Maka, manusia juga seharusnya seperti itu. Sekalipun zaman bergerak cepat dan membawanya pada perubahan, namun selama ia masih berada di bumi, ia tetap bertahan untuk hidup.

Lumut, meskipun hanya memiliki seidikit ruang di antara himpitan batu, ia tetap berusaha hidup dan berkembang. Sekali hidup, pantang baginya untuk mati. Artinya, sebanyak apapun tekanan hidup yang dihadapinya, hidup tetap harus berjalan.

Pada dasarnya, lumut tidak pernah memilih tempatnya hidup dan bertumbuh. Ia hidup bukan untuk berdiam diri di suatu tempat, ia berpindah sesuai dengan arus air di sekitarnya. Ia tidak takut akan terhanyut, karena ia tahu ujung dari semua arus air itu adalah muara di lautan. Manusia tentu bisa belajar dari sikap lumut yang seperti itu. Sebesar apapun perubahan yang dihadapi, sebanyak apapun perpindahan yang dialami, selama ia tahu tujuan hidupnya, maka tidak ada yang perlu dikhawatirkan.

\section{Filsafat Pendidikan}

Berbicara mengenai pembelajaran dan usaha mencari pengetahuan, sesungguhnya kita sedang menjajaki dasardasar dari sebuah pendidikan itu sendiri. Dasar-dasar itu lah yang kemudian disebut oleh para pemikir dengan istilah Filsafat Pendidikan. Berfilsafat pada dasarnya adalah usaha untuk memahami sesuatu dengan menyeluruh, kritis dan 
radikal. Kemudian, dengan itulah kita bisa berhati-hati dalam berpikir, berkehendak dan bertindak. Jika kita berfilsafat mengenai pendidikan, artinya kita mencoba untuk memahami pendidikan itu secara utuh dan merinci. Dengan mengetahui dasar-dasar dari pendidikan tersebut, maka kita akan paham bagaimana term and condition tipe pendidikan A agar bisa dijalankan.

Anwar dalam bukunya Filsafat Pendidikan (2015), mengatakan bahwa filsafat pendidikan yang lahir dari ilmu pengetahuan praktis mengandung maksud, bahwa tugas pendidikan sebagai aspek kebudayaan mempunyai tugas untuk menyalurkan nilai-nilai hidup. (2015: 31)

Dewey dalam Anwar (2015) menyatakan analisisnya mengenai pengertian dari Filsafat Pendidikan, yakni suatu perumusan secara tegas dan benar tentang problema pembentukan mental dan moral, dalam kaitannya menghadapi tantangan yang timbul pada kehidupan masa kini. (2015: 40)

Mengenai aliran filsafat pendidikan itu sendiri, setidaknya ada 4 aliran yang perlu diketahui, yaitu:

1. Aliran Progresivisme,

2. Aliran Essensialisme,

3. Aliran Perenialisme, dan

4. Aliran Rekonstruksialisme.

Namun kali ini, penulis hanya akan berbicara tentang aliran Progresivisme sebagai titik fokus penelaahan terhadap ornamen Rumah Gadang.

\section{Filsafat Pendidikan Progresivisme}

Aliran filsafat pendidikan progresivisme ini adalah aliran yang berkembang pesat pada permulaan abad XX dan memiliki pengaruh besar pada pembaharuan pendidikan. Progresivisme dalam pandangannya, selalu berhubungan dengan pengertian the liberal road to cultural yakni liberal bersifat fleksibel (lentur dan tidak kaku), toleran dan bersikap terbuka, serta ingin mengetahui dan menyelidiki demi pengembangan pengalaman (Anwar, 2015: 155).

Progresivisme disebut juga sebagai naturalisme, yang mempunyai pandangan bahwa kenyataan yang sebenarnya adalah alam semesta ini (Anwar, 2015:155). Ia juga juga disebut sebagai instrumentalisme karena menjadikan faktor inteligensia manusia sebagai alat atau kekuatan utama untuk memecahkan seluruh problematika manusia. Kemudian, sebutan lain untuk aliran ini adalah environmentalisme dimana aliran ini menganggap bahwa lingkungan hidup sebagai medan perjuangan untuk menghadapi tatantangan dalam hidup, baik lingkungan fisik ataupun sosial. Manusia diuji sejauh mana ia mampu beinteraksi dan bertahan dengan perubahan zaman. (Anwar, 2015: 156).

Salah satu pemikir yang sangat vokal terhadap Filsafat Pendidikan Progresivisme ini adalah John Dewey, seorang filsuf berkebangsaan Amerika yang mendedikasikan hidupnya untuk dunia pendidikan.

Mengenai aliran Progresivisme, Dewey dalam Radu (2011) mengatakan, bahwa

"...education was focused on the child's need - student was learning by doing. The authentic knowledge could be achieved only through direct experience." (2011: 87)

Dari kutipan di atas, dapat disimpulkan bahwa Dewey meletakkan kebutuhan masing-masing anak sebagai fokus dari sebuah pembelajaran. Kebutuhan tersebut akan terpenuhi secara maksimal hanya jika anak belajar sambil mempraktikkannya. Menurutnya, tidak ada cara pembelajaran yang lebih baik selain belajar langsung dari pengalaman. 
Dalam hidup akan banyak permasalahan yang dihadapi, tapi mencoba untuk memberanikan diri untuk menghadapinya akan membuat kita belajar banyak. "...finally, learning is attained by solving problems," ujar Dewey dalam Radu (2011: 89).

Sangat bertumpu pada pengalaman, membuat aliran ini kurang menyetujui adanya pendidikan yang bercorak otoritas dan absolut dalam segala bentuk seperti terdapat dalam agama, moral, politik, dan ilmu pengetahuan. Jadi jelas bahwa progres atau kemajuan, lingkungan dan pengalaman menjadi perhatian dari Progresivisme, tidak hanya angan-angan dalam dunia ide, teori dan cita-cita saja. (Anwar, 2015: 157).

\section{Menilik Prinsip Hidup Adat Minangkabau Dalam Perspektif Filsafat Pendidikan}

Pada adat Minangkabau, prinsip pendidikan alam takambang jadi guru (alam terkembang jadi guru) melandasi terbentuknya semua ornamen yang terukir di Rumah Gadang. Terbukti bahwa motif-motif ornamennya merupakan manifestasi dari flora dan fauna yang ada di alam semesta. Ukiran tersebut menjadi sebuah bentuk komunikasi visual bagi generasi berikutnya sebagai sebuah pesan untuk menghidupi hidup.

Singkatnya, alam menjadi panutan bagi manusia untuk dapat hidup dengan baik. Ini selaras dengan Filsafat Pendidikan Progresivisme.

Jika ditarik ke garis yang paling dasar, modal pertama untuk dapat belajar dengan baik adalah memiliki ketertarikan terhadap sesuatu yang ingin dipelajari. Ketertarikan tersebut akan menciptakan usaha untuk mendekati dan mengenal objek pembelajaran itu lebih jauh lagi, sekalipun harus menghadapi beberapa kesusahan. Hal ini diungkapkan oleh Dewey dalam kutipan di bawah ini,
"The method promotes the student's intrinsic motivation and spontaneous interest, and it provides the conditions necessary for undertaking an activity towards fulfilling that interest. The student mobilizes his/her effort to overcome the obstacles that may occur" (Radu, 2011:88)

Kemudian, bagaimana cara menumbuhkan ketertarikan tersebut? Biarkan setiap individu mengenal sendiri sebuah pengetahuan tanpa harus diberitahu. Seperti yang sudah disebutkan di atas, bahwa pengalaman adalah landasan awal sebuah pendidikan bagi aliran Progresivisme. Dewey dalam Radu (2011) mengatakan bahwa, "the authentic knowledge could be achieved only trhough direct experience"-pengetahuan yang otentik bisa didapatkan hanya melalui pengalaman langsung. (Radu, 2011: 87).

Selanjutnya, penulis akan mencoba melihat keterkaitan antara pendidikan Progresivisme dengan motif ornamen lumuik hanyuik.

Motif lumuik hanyuik menjelaskan tentang sesuatu yang tetap bertahan hidup di tengah perubahan. Lewat motif tersebut, adat Minangkabau hendak mendidik manusianya untuk menjadi kuat demi kelangsungan hidup. Zaman berganti seiring waktu, namun pola pikir seharusnya ikut mendewasa mengikuti perubahan zaman tersebut. Beradaptasi memang bukan perkara gampang, namun menyerah dan mati terseret arus perubahan juga pantang untuk dilakukan. Mungkin ini yang disebut-sebut oleh banyak orang, bahwa jika kamu tidak bisa merubah keadaan, maka rubahlah cara pikirmu.

Kedewasaan mental dan jiwa adalah tujuan dari pendidikan Progresivisme. Itulah yang ingin dicari lewat pengalaman. Itulah mengapa penganut paham ini mengharuskan setiap 
pribadi mencari sendiri apa yang perlu diketahuinya. Kebutuhan masing-masing individu itu berbeda, hubungan langsung antara diri sendiri dengan pengalaman itu lah yang akan memberitahunya mana hidup yang baik untuk ditinggali. Pengetahuan itu dicari, bukan ditunggu. Dewey dalam bukunya Experience and Education (1997) mengatakan, bahwa “... basing education upon personal experience may mean more multiplied and more intimate contacts between the mature and the immature than ever existed in the traditional school, and consequently more, rather than less, guidance by others." (Dewey, 1997: 21).

Dengan kata lain, orang yang sudah berpengalaman akan tahu betul cara menghadapi sebuah tantangan. Singkatnya, ia akan lebih terjaga dibandingkan yang lain.

\section{SIMPULAN}

Landasan hidup "alam takambang jadi guru" mendidik orang Minangkabau untuk menghargai alamnya dengan baik. Alam hadir bukan sekedar untuk dimanfaatkan manusia sebagai tempat tinggal dan mencari makan, namun juga menghidupi hidup. Dengan kata lain, ada pelajaran yang dapat diambil dari alam semesta ini. Pesan tersebut disampaikan dengan baik lewat ukiran-ukiran yang hadir sebagai ornamen di dinding Rumah Gadang. Sekalipun tidak semua orang memahami setiap motif secara mendalam, dengan melihat ukiran yang menyerupai daun dan bunga-bunga itu saja, orang sudah akan paham motif tersebut terinspirasi dari mana.

Untuk memahaminya lebih jauh, ukiran tersebut disertakan syair-syair dalam bahasa Minangkabau demi tersampainya maksud yang ingin dikatakan. Contohnya, motif lumuik hanyuik yang menjelaskan tentang bertahan hidup di tengah tekanan perubahan zaman.

Secara keseluruhan falsafah alam takambang jadi guru yang disampaikan lewat warisan budaya tersebut sejalan dengan misi Filsafat Pendidikan Progresivisme. Tujuan pendidikan Progresivisme adalah menciptakan manusia berpengetahuan yang siap menerima perubahan. Dan tidak ada yang lebih siap selain orang yang bersinggungan langsung dengan pengalamannya.

\section{Refleksi Kritis}

Setelah membandingkan pendidikan adat Minangkabau lewat landasan filosofis alam takambang jadi guru dengan aliran Progresivisme milik John Dewey, selain mendapatkan persamaannya, penulis juga menemukan titik perbedaannya, yaitu kepercayaan dalam bentuk apapun seperti agama, moral, politik dan ilmu pengetahun.

Progresivisme menghindarkan diri dari bentuk absolutisme bentuk apapun, termasuk agama. Tujuannya jelas, agar manusia tetap bisa berpikir terbuka, sehingga mampu menyesuaikan diri dengan zaman yang tidak pernah berhenti berubah. Dan itu berbeda dengan adat Minangkabau. Ada satu falsafah yang melandasi semua falsafah hidup yang ada di adat Minangkabau, termasuk falsafah alam takambang jadi guru, yaitu falsafah adat basandi syara', syara' basandi kitabullah. Arti dari falsafah tersebut adalah adat berlandaskan agama, agama berlandaskan kitab Allah. Dengan kata lain, segala tindak tanduk serta aturan adat harus sesuai dengan aturan agama. Mereka menghargai alam, karena memang sejalan dengan agama.

Kemudian, ada hal yang membuat penulis tergugah dan berpikir lebih dalam setelah menyelesaikan tulisan ini. Setiap penulis membahas lebih jauh mengenai ragam budaya, selalu saja didapatkan sesuatu yang unik di dalamnya. Lebih 
mengagumkan lagi, bahwa terdapat buah pikiran tajam dan maju tentang suatu hal, bahkan sebelum tradisi itu disentuh modernisasi. Sementara selama ini, ketajaman dan kemajuan pikiran selalu menjadi tolak ukur sebuah zaman. Namun, penulis berpikir bahwa, sepertinya, mereka yang lebih dahulu hidup sebelum kita lebih paham bagaimana cara mengelola hubungannya dengan alam dan sesamanya dengan lebih baik.

Dengan pemikiran tersebut, penulis berharap ada yang meneliti lebih lanjut tentang ragam budaya Indonesia umumnya, dan Minangkabau khususnya. Agar kemudian, lebih banyak pelajaran yang dapat diambil dari kebudayaan tersebut. Penulis merasa bahwa penelitian yang dilakukan kali ini belum mendalam karena hanya lewat studi literatur saja. Ditambah lagi, belum banyaknya orang yang meneliti ornamen Minangkabau beserta maknanya secara khusus membuat penulis sedikit kepayahan mencari sumbernya.

Selaras dengan metode penelitian yang penulis gunakan yaitu hermeneutika atau penafsiran, maka penelitian ini dirasa memang perlu untuk dikaji lebih dalam. Gadamer dalam Sumaryono (2016), mengatakan bahwa salah satu faktor intrepretasi adalah pengalaman. Sifat pengalaman adalah personal dan individual, jadi hanya akan valid jika diyakinkan dan diulangi oleh individuidividu yang lain. Pengalaman yang benar hanyalah yang secara historis dimiliki oleh seseorang. Orang yang berpengalaman mengetahui keterbatasan semua prediksi dan ketidaktahuan semua rencana.

\section{Glosarium}

Urang : Orang

Ranah : Tanah

\section{DAFTAR PUSTAKA}

Anwar, M. (2015). Filsafat Pendidikan. Jakarta: Prenadamedia Group.

Dewey, J. (1997). Experience and Education. USA: Touchstone.

Radu, L. (2011). John Dewey and Progressivism in American Education. E-Journal Bulletin of the Transilvania University of Brasov. Series VII: Social Sciences. Law. Vol. 4 (53) No. 2 $-2011$

Sumaryono, E. (2016). Hermeneutik, Sebuah Metode Filsafat. Yogyakarta: Kanisius

Sunaryo, A. (2009). Ornamen Nusantara - Kajian Khusus Tentang Ornamen Indonesia. Semarang : Dahara Prize.

"Arsitektur Nusantara Minangkabau" (https://ninkarch.files.wordpress. com/2008/11/ars-nus-tgsbesar.pdf) diakses pada 19 Maret 2017.

"Motif Ukiran Minangkabau" (http://zulfikri.orgfree.com/ukira n01.html) diakses pada 19 Maret 2017 